\title{
Plant Ureases: Physiological significance, role in agriculture and industrial applications - A review
}

\author{
Sandeep Kumar* \\ Department of Biochemistry and Physiology, College of Biotechnology, \\ Sardar Vallabhbhai Patel University of Agriculture \& Technology, Meerut 250110, India \\ E-mail: sandeep4554@gmail.com
}

\begin{abstract}
Urease is an important enzyme present in many organisms, including plants. This enzyme plays diverse roles and in plants it is mainly involved in the nitrogen metabolism. Here urea is primarily used as a source of nitrogen necessary for growth. It catalyzes the hydrolysis of urea to ammonium and carbamate ions, which decompose to carbon dioxide and ammonia. Urease activity is widely distributed in the soil and aquatic environment and plays essential role in nitrogen metabolism. One of the most pressing environmental issues confronting agriculture is the loss of soil nitrogen, derived from either fertilizer nitrogen or symbiotic nitrogen fixation by legumes, to the atmosphere as gases $\left(\mathrm{NH}_{3}, \mathrm{~N}_{2}\right.$ and $\mathrm{N}_{2} \mathrm{O}$, the latter being a potent greenhouse gas) or to groundwater via leaching as $\mathrm{NO}_{3}{ }_{3}$. These losses of nitrogen not only decrease nitrogen-use efficiency, and therefore have economic implications, but just as importantly, impact on groundwater quality and contribute to greenhouse gas emissions. The nitrification and urease inhibitors can be successfully used as tools to manage these losses. Urease research has major implications in agricultrure, medicine and industry. The soil urease hydrolyses urea from fertilizers to ammonia and carbon dioxide; ammonia being volatile in nature escapes into environment and causes huge economical losses as well as environmental pollution. Adulterated milk and water contamination with urea are other problem where this enzyme can play significant role.
\end{abstract}

Key words: Plant Urease, Nitrogen, structure, physiological, metabolism, immobilization.

Paper cited: Kumar, Sandeep (2015). Plant Ureases: Physiological Significance, role in Agriculture and industrial applications - A review. South Asian J. Food Technol. Environ. 1(2): 105-115.

The presence of urease (urea amidohydrolases, EC 3.5.1.5) in plants was first reported from the leaves of a legume, soybean (Glycine max) (Takeuchi, 1909). Later it was isolated and purified from several other plant sources such as jack bean (Canavalia ensiformis) (Sumner, 1926), pigeonpea (Cajanus cajan) (Das et al., 2002) watermelon (Citrullus vulgaris) (Prakash and Bhushan, 1997), and mulberry (Morus alba) (Hirayama et al., 2000). Urease research had made a significant contribution in the field of enzymology since 1926, when it was isolated and crystallized from jack bean (Canavalia ensiformis) by James Sumner (Sumner, 1926) and was shown to be proteinaceious in nature. He got Nobel Prize for Chemistry in 1946 for making this fundamental contribution to modern enzymology. He postulated that all enzymes are proteins; an important notion which was further supported by later workers.

Later, Dixon and co-workers showed that urease contains nickel in its active site (Dixon et al., 1975) and since then, urease remained as the only nickelcontaining metalloenzyme identified so far in plants
(Polacco, 1977). Its rapid catalysis for the hydrolysis of urea to ammonia and carbon dioxide plays an essential role in agriculture and human health (Mulvaney and Bremner, 1981; Mobley et al., 1995). The plant and fungal ureases are homo-oligomeric proteins (consist of identical subunits), while the bacterial ureases are multimers formed from a complex of two or three subunits (Mobley et al., 1995; Tange and Niwa, 1997). The high amino acid sequence similarity among all ureases indicates that all ureases are variants of the same enzyme and are likely to possess similar tertiary structures and catalytic mechanisms (Mobley et al., 1995). This conclusion is supported by the available biochemical and structural data obtained for the best-characterized ureases, e.g., from jack bean (Hirai et al., 1993) and $K$. aerogenes (Jabri et al., 1995). Structure studies, inhibition studies and immobilization work on plant urease have added much in the last two decades in the overall understanding of urease. Present review attempts to compile the findings from such studies to bring a clear, comprehensive and thorough 
understanding of structure, physiological role and industrial applications of plant ureases.

\section{Biochemistry of urea catalysis}

Urea is an organic compound with the chemical formula $\left(\mathrm{NH}_{2}\right)_{2} \mathrm{CO}$. It was the first organic compound to be artificially synthesized from inorganic starting materials, in 1828 by Friedrich Wöhler, who prepared it by the reaction of potassium cyanate with ammonium sulfate. It is a nitrogencontaining chemical product that is produced on a scale of some $10^{8}$ tons per year worldwide. For use in industry, urea is produced from synthetic ammonia and carbon dioxide. More than $90 \%$ of world production is destined for use as a fertilizer. Urea has the highest nitrogen content of all solid nitrogenous fertilizers in common use (46.7\%). Urea is highly soluble in water and is, therefore, also very suitable for use in fertilizer solutions. Urea is a powerful protein denaturant. This property can be exploited to increase the solubility of some proteins. For this application, it is used in concentrations up to $10 \mathrm{M}$. Urea is used to effectively disrupt the non-covalent bonds in proteins.

Urea is constantly released into the environment due to the biological activity of various organisms e.g., in urine/uric acid of mammals, birds, reptiles and most terrestrial insects. Also urea is the product of various metabolic pathways such as catabolism of purine, arginine, agmatine, allantoin, and allantoic acid (Vogels and Drift, 1976). Urea finally liberated into the environment is further metabolized with the action of enzyme, urease. The products of this reaction are ammonia and carbamate, the latter spontaneously hydrolyzing to carbonic acid and a second molecule of ammonia in an uncatalyzed reaction (Mobley et al., 1995; Hausinger, 1993; Mobley and Hausinger, 1989; Andrews et al., 1984).

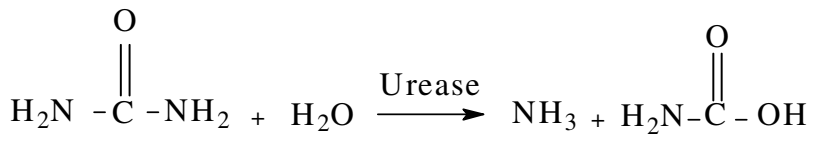<smiles></smiles>

Ammonia molecules thus formed are protonated by water at physiological $\mathrm{pH}$, whereas the carbonic acid dissociates and causes an increase in $\mathrm{pH}$.

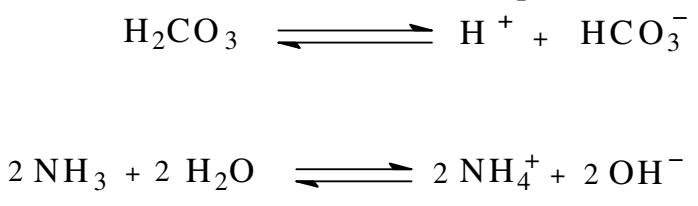

Spontaneous degradation of urea occurs with a half-life of approximately 3.6 years, but in the presence of urease, the hydrolysis of urea is $10^{14}$ times faster (Zerner, 1991)). Although urea is the major substrate of urease, this enzyme is capable of hydrolyzing (albeit poorly) other substrates such as acetamide, formamide, $N$-methylurea, semicarbazide, and hydroxyurea (Dixon et al., 1980). Urease from most of the plant sources reported so far shows $K_{\mathrm{m}}$ in the range 0.1-5 mM urea (Das et al., 2002; Hirayama et al., 2000; Blakeley et al., 1969) while bacterial ureases possess $K_{m}$ values ranging from 0.1 to $>100$ $\mathrm{mM}$ urea (Mobley and Hausinger, 1989). Optimum operational conditions for most of the plant ureases have been reported at $\mathrm{pH} 7-8$ and temperature 35$45^{\circ} \mathrm{C}$ (Das et al., 2002; Hirayama et al., 2000; Blakeley and Zerner, 1984).

Most organisms have to deal with the excretion of nitrogen waste originating from protein and amino acid catabolism. In aquatic organisms the most common form of nitrogen waste is ammonia, while land-dwelling organisms convert the toxic ammonia to either urea or uric acid. In general, birds and saurian reptiles excrete uric acid, whereas the remaining species, including mammals, excrete urea. Despite the generalization above, the pathway has been documented not only in mammals and amphibians but in many other organisms as well, including birds, invertebrates, insects, plants, yeast, fungi, and even microorganisms.

\section{A Ubiquitous enzyme}

Urease is a ubiquitous enzyme which is wide spread in nature, being present in several forms of life ranging from bacteria to plants and animals. It has different functions in different organisms e.g., in some organisms, it has defensive role while in others it plays role in energy metabolism. Although urease is a cytosolic enzyme in many organisms including yeast, bacteria and plants (Delisle, 1977; Faye et al., 1986; Jeffries, 1964), but some studies indicate a periplasmic or membrane-bound location (McLean $e t$ al., 1985; McLean et al., 1986). Many eukaryotes synthesize urease, including plants other than jack bean (Polacco, 1977; Granick, 1937), some invertebrates (McDonald et al., 1980), and numerous eukaryotic microorganisms. Also, urease activity is widely observed among the prokaryotes, including many eubacteria and at least one archaebacterium, Methanobacterium thermo-autotrophicum (Bhatnagar et al., 1984). In plants it liberates nitrogen from the protein reserves of cotyledons to the developing embryo during germination. The presence of two isozymes for urease has been reported in soybean (Holland et al., 1987). Ubiquitous urease is synthesized in all organs (constitutively expressed) 
but it appears to be most active in young tissues (Holland et al., 1987; Polacco and Winkler, 1984; Polacco et al., 1985; Polacco et al., 1989). Embryospecific urease is synthesized exclusively in the developing embryos, although roots of young soybean plant retain considerable embryo-specific urease derived from the embryonic axis (Torisky and Polacco, 1990).

\section{Physiological significance of urease in plants:}

Many species of leguminosae have high levels of urease activity in their seeds. For example, the extractable protein from soybean is at least $0.2 \%$ urease (dry-weight), whereas in jack bean, urease comprises $0.15 \%$ (Polacco and Sparks, 1982). Urease, beside urea amidolase, is an essential ureadegrading enzyme in plants that catalyzes urea assimilation after uptake into plant cells. Not entirely yet elucidated, higher plants were shown to possess various urea transport systems, passive and active, which allow them to optimize N-nutrition depending on the nitrogen form available from external environment or internally synthesized. From external environment, plants assimilate urea through roots as urea, but essentially as ammonia generated from urea hydrolysis, and this is possible due to the presence of ureases in soils, a fact exploited in urea fertilization practices. The availability of fixed nitrogen is the major limitation to agricultural productivity. Two major forms of fixed nitrogen in the environment are proteins and polynucleotides. These components are hydrolyzed to the amino acid and nucleotide monomers and then further degraded by a variety of enzymes. The guanidino group of arginine and the ring nitrogens of purines are released as urea, which is further hydrolyzed by urease (Vogels and Drift, 1976; Varner, 1959). The product ammonia can be taken up and utilized by soil microbes and plants. In bacteria, the enzyme urease, as in other species, catalyzes the hydrolysis of urea. Urea hydrolysis in most bacteria is used as a nitrogen or carbon source for anabolic processes.

Primarily, urease allows plants and microorganisms to utilize urea, internally derived or external, to generate ammonia as a nitrogen source for growth (Mobley and Hausinger, 1989; Ciurli and Mangani, 2001; Hausinger and Karplus, 2001). In organisms containing the enzyme urease, urea is primarily used as a source of nitrogen necessary for growth. There are at least three key enzymes involved in urea metabolism in plants: arginase, urease and glutamine synthetase. Significant amounts of plant nitrogen flow through urea. This compound derives from arginine and possibly from degradation of purines and ureides. The nitrogen present in urea is unavailable to the plant unless hydrolyzed by urease. The product of urease activity - ammonia - is incorporated into organic compounds mainly by glutamine synthetase. It has been reported that overexpression of the pine glutamine synthetase in transgenic poplar improves the growth of the plants, probably by increasing the efficiency of nitrogen utilization (Gallardo et al., 1999). On the other hand, it has been shown that increased activity of this enzyme in the roots of a legume plant, Lotus japonicus, leads to decreased plant biomass production, possibly due to limited nitrate uptake (Limami et al., 1999). These results, which seem contradictory at first glance, might reflect the different roles of glutamine synthetase isoenzymes in different plants and/or different plant organs. They indicate the significance of this enzyme for plant nitrogen metabolism. The activity of glutamine synthetase, the amount of its product, glutamine, and possibly the availability of its substrate, ammonia, seem to be important factors controlling nitrogen metabolism and affecting plant growth (Stitt, 1999; Wiren et al., 2000).

In many environments the level of available nitrogen compounds is inadequate for optimal crop production. Therefore, fertilizers are applied which can be converted to a form of nitrogen that plants can assimilate. Importantly, high inputs of urea fertilizers applied may constitute a serious hazard both to plants and the environment. To enhance fertilization practices, urea is also applied through the foliage. Absorbed rapidly, foliar-applied urea, however, can be toxic in high concentrations. Clearly, further knowledge on the mechanisms of urea-related plant nutrition is needed for the development of balanced strategies of urea-fertilization for best and sustainable agricultural crop production.

In soybean, the dispensability of ureases is still in question (Goldraij et al., 2003). Soybean contains an ubiquitous urease that is synthesized in all tissues, as well as an embryo-specific urease that is confined to the developing embryo and is retained in mature seeds where its activity is roughly 1000fold greater than that of ubiquitous urease (Goldraij et al., 2003, Polacco and Holland, 1993). Therefore, it has been suggested that embryo-specific urease probably has no essential physiological function related to urea hydrolysis (Stebbins et al., 1991). In vitro studies with developing cotyledons of pea (Lea et al., 1979) and soybean seedlings (Thompson et al., 1977; Stebbins and Polacco, 1995) indicated that urease(s) play little or no role in embryo nutrition. Since the developing soybean embryo does not generate urea, the obvious question is why the developing soybean embryo would invest in a very active ureolytic protein when it never "sees" urea. The abundant seed urease appears to be 
nonassimilatory and it has been hypothesized that it may be involved in a plant defense function.

In combination with arginase, urease has been proposed to function in the utilization of the seed protein reserves during germination. Nevertheless, the physiological relevance of ureases, at least in certain plants, is still unclear. The obvious question from these findings is what is the role of these different ureases in the plant? Do these enzymes have physiological properties other than ureolytic activity? Carlini and Guimara es (1981) isolated canatoxin, a highly toxic protein from jack beans that induces convulsions and death in mice and rats when injected intraperitoneally. Canatoxin was subsequently identified as an isoform of urease (Follmer et al., 2001) which can be isolated separately from jack bean urease using their different affinities for metal ions (Follmer et al., 2004). Unlike jack bean urease, canatoxin is a homodimer of 95 kDa subunits (Follmer et al., 2001). It has also been hypothesized that due to the generation of ammonia, urease fulfils a defense function against plant pathogens (Polacco and Holland, 1993). In the same context, evidence has been provided that independent of their ureolytic activity, ureases also exhibit antifungal properties, suggestive of their function in plant defense system.

\section{Crystal Structure of Jack bean Urease}

The crystals of jack bean urease (Sumner, 1926) have long been available. Jabri et al., (1992) have produced the octahedral crystals of jack bean urease and obtained crystals of $K$. aerogenes urease by the hanging drop method. Sumner's work provided the proof about the proteinaceous nature of enzymes, and also demonstrated that proteins can be crystallized. Currently more than 14 urease structures have been solved at $2.5 \AA$ resolution or better. These include wild-type urease at ambient and cryogenic temperatures, the urease apoenzyme, and many mutants. An overlay of all of these structures allows three clear conclusions to be drawn; first, the bulk of the protein including all of the metal ligands and most of the groups lining the active site are well superimposable in all of the structures; second, the active site flap varies in terms of conformation and mobility among the structures, in some mutants being better fixed and in others being so disordered as to be invisible in the electron density map; and third, the hydration pattern of the nickel ions varies greatly between the structures. To date, X-ray crystal structures of the native enzyme, mutants, and inhibitor complexes from three microbes, Klebsiella aerogenes, Bacillus pasteurii, and $H$. pylori, have been determined and analyzed. Among the plant ureases, only the crystallization and preliminary $\mathrm{X}$ - ray analysis of jack bean urease were reported earlier (Jabri et al., 1992).

Recently urease from two different plant sources namely, pigeonpea (Cajanus cajan) and jack bean (Canavalia ensiformis) have been crystallization and preliminary X-ray analysis has been carried out by Balasubramanian and Ponnuraj (2008, 2009). These reports on plant ureases is of its first kind in the context of structure elucidation of plant urease and their catalytic mechanism, which otherwise largely understood and based on earlier studies on bacterial ureases. The pigeonpea urease was crystallized and the resulting crystals diffracted to 2.5 $\AA$ resolution. The crystals belonged to the rhombohedral space group R32, with unit-cell parameters $\mathrm{a}=\mathrm{b}=176.29, \mathrm{c}=346.44 \AA$ (Balasubramanian and Ponnuraj, 2008). The jack bean urease was crystallized and the resulting crystals diffracted to $2.05 \AA$ resolution using synchrotron radiation. The crystals belonged to the hexagonal space group P6322, with unit-cell parameters $\mathrm{a}=\mathrm{b}=$ 138.57, $\mathrm{c}=198.36 \AA$. More recently, the crystal structure of the first plant urease from jack bean has been solved at $2.05 \AA$ resolutions and it took around 83 Years from its first crystal to molecular structure determination. They found that the active-site architecture of jack bean urease is similar to that of bacterial ureases containing a binickel center.

Plant and fungal ureases are homooligomeric proteins of $90-\mathrm{kDa}$ identical subunits, while bacterial ureases are multimers of two- or three-subunit complexes. The bacterial and plant ureases have high sequence similarity, suggesting that they have similar three-dimensional structures and a conserved catalytic mechanism (Mobley et al., 1995; Follmer, 2008). A single subunit of plant ureases is made up of a single-chain polypeptide and is comparable to the whole urease structure in bacteria, which consist of two or three polypeptides (subunits) designated as $\alpha, \beta$, and $\gamma$.

The jack bean urease exists as a trimer or a hexamer of identical 90- kDa subunits (Dixon et al., 1975; Dixon et al., 1980) with each subunit containing two nickel ions. A hammer or T-shaped jack bean urease monomer consists of four domains: the $N$-terminal $\alpha-\beta$ domain (magenta, handle of the hammer), another $\alpha-\beta$ domain (red, one end of the hammer head), a- $\beta$ domain (yellow, the middle region of the hammer head), and C-terminal $(\alpha-\beta) 8$ TIM barrel domain (green, other end of the hammer head). The major structural difference observed between jack bean urease and bacterial ureases are at the gap regions between the $\gamma, \beta$, and $\alpha$ subunits and at a loop region that covers the active site. On the basis of the similarities in sequence and reaction kinetics, it has been assumed those known ureases 
have a common structure and catalytic mechanism and so we can use much of the information obtained for the structure and catalytic mechanism of bacterial ureases to understand plant ureases.

The detailed description of active site structure as well as the mechanism of urease proposed by Balasubramanian and Ponnuraj (2008, 2009). Each subunit hosts an active site characterized by the presence of a binuclear nickel center. The metal ions are located roughly half-way down a deep active-site cleft. The two nickel ions are bridged by the carboxylate group of the carbamylated Lys490*, bound to $\mathrm{Ni}(1)$ through $\mathrm{O}^{\delta 1}$ and to $\mathrm{Ni}(2)$ through $\mathrm{O}^{\delta 2}$. $\mathrm{Ni}(1)$ is further coordinated by His519 $\mathrm{N}^{\delta 1}$ and His545 $\mathrm{N}^{\varepsilon 1}$, while $\mathrm{Ni}(2)$ is bound to His407 $\mathrm{N}^{\varepsilon 2}$, His409 $\mathrm{N}^{\varepsilon 2}$ and Asp633 $\mathrm{O}^{\delta 1}$. Both nickel ions are well ordered and the two are separated by $3.7 \AA$. The superposition of active-site region of jack bean urease with native Klebsiella aerogenes, Bacillus pasteurii, and Helico pylori revealed that the overall architecture is very similar.

Phosphate moiety is tetrahedrally spaced towards the open side of the active-site cleft in the vicinity of the two nickel ions whereas in bacterial ureases, four well-ordered water/hydroxide molecules spaced tetrahedrally. Phosphate moiety forms four coordination bonds with the two $\mathrm{Ni}$ ions. The phosphate oxygen atom $\mathrm{O}^{\delta 4}$ symmetrically bridges $\mathrm{Ni1}$ and $\mathrm{Ni2}$ at a distance of 2.12 and $2.20 \AA$, respectively and the other two phosphate oxygen atoms such as $\mathrm{O}^{\delta 1}$ and $\mathrm{O}^{\delta 2}$ interact with $\mathrm{Ni1}$ and $\mathrm{Ni} 2$ at a distance of 2.16 and $2.35 \AA$, respectively. The Ni1-bound phosphate oxygen forms an additional hydrogen bond with His492 $\left(\mathrm{N}^{\varepsilon 2}\right)$ at $2.81 \AA$. The fourth phosphate oxygen $\mathrm{O}^{\delta 4}$ (distal) is directed into the active-site channel. Closer comparison of the active-site regions of jack bean urease and phosphateinhibited Bacillus pesturii urease indicates that the arrangements of protein ligands around the $\mathrm{Ni}$ ions in both the structures are essentially identical.

The enzyme active site accurately designed to selectively bind the substrate in an orientationspecific mode, and subsequently to stabilize a tetrahedral transition state. Urea enters the active-site cavity when the flap is in the open conformation, replacing two phosphate (jack bean urease) or water molecules (bacterial urease), which are located in positions matching its molecular shape and dimensions. Chemical modification studies have provided clear evidence for the presence of cysteine, histidine, and arginine residues at the urease active site and it has been shown that a histidine and a sulfhydryl group of active site play essential role in urea catalysis (Kumar and Kayastha, 2010; Prakash and Upadhyay, 2003; Srivastava and Kayastha, 2000).

\section{Role in Agriculture and Nitrogen cycle}

In agriculture, high urease activity (soil bacteria) causes significant environmental and economic problems by releasing abnormally large amounts of ammonia into the atmosphere during urea fertilization. Accumulation of ammonium ions, loss of urea $\mathrm{N}$ as ammonia, nitrite as well as ammonia toxicity damages germinating seeds, seedlings, and young plants (Gasser, 1964; Tomlinson, 1970; Radel et al., 1988). These problems can be successfully tackled by undertaking the inhibition studies of urease of ureolytic bacteria (found in soil) and from any other source as model system. These inhibitors can then be successfully applied in conjunction with fertilizers. A number of studies have demonstrated that this approach can be very fruitful. In last several years, a number of compounds have been synthesized and patented as inhibitors of urea hydrolysis in soil (Andrews et al., 1984; McCarty et al., 1990).

In addition to their potential value in medicine and agriculture, the study of urease inhibitors can provide insight into selected aspects of the enzyme mechanism and active-site structure. The discovery of urease inhibitors has to-date mainly relied upon random screening of tens of thousands of chemical compounds. However, with the determination of high-resolution X-ray structures of native and inhibited ureases from $K$. aerogenes (Jabri et al., 1995) and B. pasteurii (Benini et al., 1999), it is now possible to rationally search for these inhibitors. These structural studies have revealed the intimate details of the molecular geometry of the enzyme as well as mechanism of urea hydrolysis, which has paved the way for structure-based design of potent inhibitors. Several classes of urease inhibitors are known, and some have been examined for their pharmacological and agricultural value (Mulvaney and Bremner, 1981; Mobley and Hausinger, 1989; Zerulla et al., 2000). Studies on inhibitors are useful to learn about how enzymes interact with their substrates; role of inhibitors in enzyme regulation; drugs if they inhibit aberrant biochemical reactions; understanding the role of biological toxins; insecticides etc.

Soil ammonium $\left(\mathrm{NH}_{4}^{+}\right)$is derived from several sources: directly from the mineralization of organic matter and the addition of ammoniumcontaining fertilizers, and, indirectly, as the result of the hydrolysis of applied urine and fertilizer urea. Under typical conditions ammonium is oxidized first to nitrite $\left(\mathrm{NO}_{2}^{-}\right)$by a specific bacteria (Nitrosomonas) and then to nitrate $\left(\mathrm{NO}_{3}{ }^{-}\right)$by the bacteria (Nitrobacter). This process is known as nitrification. The relative speed of these reactions is such under normal soil conditions that ammonia and nitrate concentrations in soils are low, relative to nitrite. 
However, plants can utilize both ammonium and nitrate. $\mathrm{NO}_{3}{ }^{-}$is soluble and negatively charged and is not held to any extent by the soil. It is therefore subject to leaching under the appropriate conditions. In contrast, $\mathrm{NH}_{4}{ }^{+}$is positively charged and retained as a cation by the soil cation exchange capacity (CEC). Furthermore, under anaerobic conditions $\mathrm{NO}_{3}{ }^{-}$nitrogen can be reduced by denitrifying bacteria to the gases $\mathrm{N}_{2} \mathrm{O}$ and $\mathrm{N}_{2}$ (denitrification). These gases can also be produced from ammonia and nitrite under aerobic conditions by chemical reactionschemodenitrification. For these reasons, controlling the processes of nitrification and/or urease hydrolysis are, theoretically at least, potential tools to restrict nitrogen leaching, greenhouse gas emissions and ammonia volatilization from soils. As a consequence the nitrogen cycle should be more efficient and nitrogen use efficiency increased. It has focused therefore on the use of nitrification inhibitors in conjunction with fertilizer nitrogen and animal wastes, and urease inhibitors applied with urea-based fertilizer.

The most common nitrification inhibitors includes, Nitrapyrin (2-chloro-6 (trichloromethyl) pyridine), dicyandiamide (DCD) and more recently DMPP (3,4 dimethylpyrazole-phosphate) (Zerulla et al., 2000). There are several reviews on the development of urease inhibitors in the literature (Gould et al., 1986) and while many chemicals have been tested, only one has been developed through to registration, ( $N$-(n-butyl) thiophosphoric triamide; trade name Agrotain). The most common nitrification inhibitor is DCD. It is not a biocide and has no effect on soil microbial biomass (Amberger, 1989). It acts specifically on an enzyme (ammonia monooxygenase) contained in Nitrosomonas, by blocking the site where ammonium is converted to nitrite. The Agrotain has no effect on the size and activity of soil biomass (Kucharski, 1992; Banerjee et al., 1999) and acts by blocking the active site of the urease enzyme.

Nitrification inhibitors restrict the microbial conversion of ammonium $\left(\mathrm{NH}_{4}{ }^{+}\right)$to $\mathrm{NO}_{3}{ }^{-}$and hence to the gases, $\mathrm{N}_{2}$ and $\mathrm{N}_{2} \mathrm{O}$ (a greenhouse gas) in soil. Ammonia volatilization, from either urea or urine, is greater under conditions of high soil $\mathrm{pH}$, coupled with warm, moist soils under windy conditions. Urease inhibitors restrict the conversion of urea and urine to ammonium, and hence to nitrate, in soils.

The majority of the research indicates that nitrification inhibitors, when applied to soils in conjunction with nitrogen fertilizers or animal wastes, have beneficial effects on reducing nitrate leaching and nitrous oxide emissions, and, as a result increase plant growth (Prasad and Power, 1995; Williamson et al., 1998; Merino et al., 2002). Urea can damage seedlings and inhibit germination (because of the accumulation of high concentrations of $\mathrm{NH}_{4}{ }^{+}$. By slowing the rate of hydrolysis, Agrotain can reduce this effect (Wang et al., 1995; Malhi et al., 2003). There is also evidence of phytotoxicity associated with the use of Agrotain (Krogmeier et al., 1989). This is caused by the uptake of urea by plants, which causes leaf-tip scorch. It is not known whether this is a direct toxicity of urea or an indirect effect, however, it is transitory and occur in situations where high rates of urea and the inhibitor are used. Earlier reports on various inhibitors of plant ureases have demonstrated the relevance of studies in catalytic mechanism of urease, agriculture and environment (Dixon et al., 1980; Kumar and Kayastha, 2010; Kumar and Kayastha, 2010; Todd and Hausinger, 1989; Breitenbach and Hausinger, 1988; Todd and Hausinger, 2000).

\section{Immobilization and Industrial Applications}

Enzyme immobilization has been a prerequisite for industries based on enzyme hydrolyzed products. Several methods of enzyme immobilization have been known, each of them have their own limitations and benefits. Adsorption is simple, cheap and effective but frequently reversible, covalent attachment and cross-linking are effective and durable, but expensive and easily worsening the enzyme performance, and in membrane reactorconfinement, entrapment and microencapsulations, diffusional problems are inherent. The immobilized enzyme offers the advantage of better $\mathrm{pH}$, temperature and storage stability over free urease; can be used repeatedly and also offers promise in diagnostics. In countries like India, where adulteration of urea in commercialized milk have been reported, these immobilized preparation may prove to be a valuable tool for estimating urea in such samples by unskilled persons. Diverse enzyme immobilization techniques have been developed (Sheldon, 2007; Krajewska, 2004). The choice of materials to be used in these techniques is practically unlimited, and include organic and inorganic, natural and synthetic materials, that may be configured as (micro-, nano-)beads, membranes, fibers, hollow fibers, (micro-)capsules, sponges to best suite a chosen biotransformation in a chosen bioreactor. Enzyme immobilizations onto matrices which are non-toxic, cheap, renewable and biodegradable have utmost importance in food, cosmetics, biomedical, or pharmaceuticals applications (Hoffman, 2002). Biopolymers like alginate, chitin, chitosan, agarose, agar etc. have been worthy matrices for enzyme immobilization (Rinaudo, 2008).

The immobilization alters the properties of enzymes (Table 1). For the most cases the enzyme 
Table 1: Comparison of percent immobilization and other kinetic properties of ureases from different sources on various support materials.

\begin{tabular}{|c|c|c|c|c|c|c|c|c|c|c|c|}
\hline \multirow[t]{2}{*}{$\begin{array}{c}\text { Plant source }+ \\
\text { matrix }\end{array}$} & \multirow[t]{2}{*}{$\begin{array}{l}\text { Mode of } \\
\text { binding }\end{array}$} & \multirow{2}{*}{$\begin{array}{c}\% \\
\text { Immobi } \\
\text { lization }\end{array}$} & \multicolumn{2}{|c|}{$\begin{array}{c}\text { Optimum } \\
\text { temperature }\left({ }^{\circ} \mathrm{C}\right)\end{array}$} & \multicolumn{2}{|c|}{$\begin{array}{c}\text { Optimum } \\
\text { pH }\end{array}$} & \multicolumn{2}{|c|}{$\begin{array}{c}\mathbf{K m} \\
(\mathbf{m M})\end{array}$} & \multicolumn{2}{|c|}{$\begin{array}{c}\text { Half life at } 4^{\circ} \mathrm{C} ; t_{1 / 2} \\
\text { (days) }\end{array}$} & \multirow[t]{2}{*}{ References } \\
\hline & & & Soluble & $\begin{array}{c}\text { Immobil } \\
\text { ized }\end{array}$ & Soluble & $\begin{array}{l}\text { Immobil } \\
\text { ized }\end{array}$ & Soluble & $\begin{array}{l}\text { Immobil } \\
\text { ized }\end{array}$ & Soluble & $\begin{array}{l}\text { Immobil } \\
\text { ized }\end{array}$ & \\
\hline $\begin{array}{l}\text { Glycine max }+ \\
\text { chitosan }\end{array}$ & Covalent & $77 \%$ & 65 & 75 & 7 & 7.9 & 2.70 & 3.92 & 19 & 80 & Kumar et al., (2009) \\
\hline $\begin{array}{l}\text { Glycine } \max + \\
\text { alginate }\end{array}$ & $\begin{array}{l}\text { Entrap } \\
\text { - ment }\end{array}$ & $54 \%$ & 65 & 80 & 7 & 6.2 & 2.70 & 5.88 & 19 & 121 & Kumar et al., (2009) \\
\hline $\begin{array}{l}\text { Canavalia } \\
\text { ensiformis }+ \\
\text { gelatin }\end{array}$ & Covalent & $67.6 \%$ & 45 & 60 & 7.3 & 8.0 & -- & --- & 20 & 90 & Kumar et al., (2005) \\
\hline $\begin{array}{l}\text { Cajanus cajan }+ \\
\text { chitosan }\end{array}$ & Covalent & $64 \%$ & 47 & 77 & 7.3 & 8.5 & 3.0 & 8.3 & 21 & 110 & $\begin{array}{l}\text { Kayastha and Srivastava, } \\
\text { (2001) }\end{array}$ \\
\hline $\begin{array}{l}\text { Cajanus cajan }+ \\
\text { gelatin }\end{array}$ & Covalent & $75 \%$ & 47 & 65 & 7.3 & 6.5 & 3.0 & 8.3 & 21 & 240 & Srivastava et al., (2001) \\
\hline $\begin{array}{l}\text { Cajanus cajan }+ \\
\text { agar }\end{array}$ & $\begin{array}{l}\text { Entrap } \\
\text { - ment }\end{array}$ & $51.7 \%$ & 47 & 60 & 7.3 & 7.5 & 3.23 & 5.07 & 21 & 53 & Swati et al., (2007) \\
\hline $\begin{array}{l}\text { Cajanus cajan }+ \\
\text { alkylamine glass }\end{array}$ & Covalent & $92.5 \%$ & 47 & 77 & 7.3 & 6.8 & 3.35 & 3.55 & 21 & (a) & $\begin{array}{l}\text { Reddy and Kayastha, } \\
\text { (2006) }\end{array}$ \\
\hline $\begin{array}{l}\text { Cajanus cajan }+ \\
\text { arylamine glass }\end{array}$ & Covalent & $90 \%$ & 47 & 77 & 7.3 & 7.0 & 3.35 & 3.43 & 21 & (a) & $\begin{array}{l}\text { Reddy and Kayastha, } \\
\text { (2006) }\end{array}$ \\
\hline $\begin{array}{l}\text { Cajanus cajan + } \\
\text { DEAE-cellulose } \\
\text { paper }\end{array}$ & $\begin{array}{l}\text { Adsorp } \\
\text {-tion }\end{array}$ & $51 \%$ & 47 & 67 & 7.3 & 6.8 & 3.0 & 4.75 & 21 & 150 & Reddy et al., (2004) \\
\hline $\begin{array}{l}\text { Cajanus cajan + } \\
\text { polyacrylamide gel }\end{array}$ & $\begin{array}{l}\text { Entrap } \\
\text { - ment }\end{array}$ & $50 \%$ & -- & -- & -- & -- & -- & -- & 21 & 200 & Das et al., (1998) \\
\hline $\begin{array}{l}\text { Cajanus cajan }+ \\
\text { alginate beads }\end{array}$ & $\begin{array}{l}\text { Entrap } \\
\text {-ment }\end{array}$ & $50 \%$ & -- & -- & -- & -- & -- & -- & 21 & 75 & Das et al., (1998) \\
\hline $\begin{array}{l}\text { Cajanus cajan }+ \\
\text { cotton cloth }\end{array}$ & Covalent & $56 \%$ & -- & -- & -- & -- & -- & -- & 21 & 70 & Das and Kayastha, (1998) \\
\hline
\end{tabular}


activity is lowered and its Michaelis constant increased. These alterations are a combined effect of a number of factors. One is brought about by structural changes in the enzyme occurring as a result of its binding, the other ones resulting from the heterogeneity of the system. These include creation of a microenvironment different from the bulk solution, strongly depending on the properties of the support (electric charge, hydrophobicity, etc.), the reaction itself (ions, $\mathrm{pH}$ change, etc.) and on the design of the reactor, in addition to inevitable mass transfer limitations. Effectively, it is both the enzyme and the support, and the interaction between the two that impart the system with specific physico-chemical and kinetic properties responsible for its operational performance. By contrast, for the enzyme system to be characterized, the following properties are relevant: specific activity, the Michaelis constant $K_{m}$, the optimum $\mathrm{pH}$ and temperature, and the activation energy, these properties typically compared to the free enzyme. Obviously, a major emphasis in practical applications is on the stability of the enzyme. This includes thermal and storage stabilities, also compared to the free enzyme, in addition to operational stability and reusability.

Immobilizations of a great variety of enzymes have been studied for the application in diverse analytical, medical, industrial and biotechnological processes, and to date, several processes have been implemented on a larger scale, mainly in the food industry and in the manufacture of fine specialty chemicals and pharmaceuticals (Krajewska, 2004). Among enzymes most extensively studied for immobilizations and practical applications are ureases. This is because of the significance of the processes in which ureases take part and of their possible exploitation in practical applications. Urease from several plant sources has been immobilized and characterized on a variety of matrices and have been demonstrated for their industrial applications (Kumar et al., 2009; Kumar et al., 2005; Kayastha and Srivastava, 2001; Swati et al., 2007; Das et al, 1998; Das and Kayastha, 1998; Reddy et al., 2004).

\section{References}

1. Amberger, A. (1989). Research on dicyandiamide as a nitrification inhibitor and future outlook. Commun Soil Sci Plant Anal. 20: 1933-1955.

2. Andrews, R.K., Blakeley, R.L., Zerner, B. (1984). Urea and urease. In: Advances in Inorganic Biochemistry (Eds, Eichhorn, G.L. and Marzilli, L.G.) Elsevier Pub, New York. Vol. 1 pp: 245-283.

3. Balasubramanian, A, and Ponnuraj, K. (2009). Purification, crystallization and preliminary $\mathrm{X}$ - ray analysis of urease from jack bean (Canavalia ensiformis). Acta Cryst. F. 65: 949951

4. Balasubramanian, A. and Ponnuraj, K. (2008). Purification, crystallization and preliminary $\mathrm{X}$ ray analysis of urease from pigeonpea (Cajanus cajan). Acta Cryst F. 64: 662-664.

5. Banerjee, M.R., Burton, D.J. and Grant, C.A. (1999). Influence of urea fertilization and urease inhibitors on the size and activity of soil microbial biomass under conventional and zero tillage at two sites. Can J Soil Sci. 79: 255-263.

6. Benini, S., Rypniewski, W.R., Wilson, K.S., Miletti, S., Ciurli, S. and Mangani, S. (1999). A new proposal for urease mechanism based on the crystal structures of the native and inhibited enzyme from Bacillus pasteurii: why urea hydrolysis costs two nickels. Structure. 7: 205216.

7. Bhatnagar, L., Jain, M. K., Aubert, J. P. and Zeikus, J.G. (1984). Comparison of assimilatory organic nitrogen, sulfur, and carbon sources for growth of Methanobacteriumn species. Appl. Environ. Microbiol. 48: 785-790.

8. Blakeley, R.L., Webb, E.C. and Zerner, B. (1969). Jack bean urease (EC 3.5.1.5). A new purification and reliable rate assay. Biochemistry. 8: 1984-90.

9. Blakeley, R.L. and Zerner, B. (1984). Jack bean urease: The first nickel enzyme. J Mol Cat. 23: 263-292.

10. Breitenbach, J.M. and Hausinger, R.P. (1988). Proteus mirabilis urease. Partial purification and inhibition by boric acid and boronic acids. Biochem J. 250: 917-920.

11. Carlini, C.R. and Guimarães, J.A. (1981). Isolation and characterization of a toxic protein from Canavalia ensiformis (jack bean) seeds, distinct from concanavalin. Toxicon. 19: 667675.

12. Das, N., Kayastha, A.M. and Malhotra, O.P. (1998). Immobilization of urease from pigeonpea (Cajanus cajan L.) in polyacrylamide gels and calcium alginate beads. Biotechnol Appl Biochem. 27: 25-29.

13. Das, N., Kayastha, A.M. and Srivastava, P.K. (2002). Purification and characterization of urease from dehusked pigeonpea (Cajanus cajan L.) seeds. Phytochemistry. 61: 513-521.

14. Das, N. and Kayastha, A.M. (1998). Immobilization of urease from pigeonpea (Cajanus cajan L.) on flannel cloth using polyethyleneimine. World J Microbiol Biotechnol. 14: 927-929. 
15. Delisle, G. J. (1977). Multiple forms of urease in cytoplasmic fractions of Ureaplasma urealyticum. J. Bacteriol. 130: 1390-1392.

16. Dixon, N.E., Gazzola, C., Blakeley, R. and Zerner B. (1975). Jack bean urease (E.C. 3.5.1.5). A metalloenzyme. A simple biological role for nickel? J Am Chem Soc. 97: 41314133.

17. Dixon, N.E., Riddles, P.W., Gazzola, C., Blakeley, R.L. and Zerner, B. (1980). Jack bean urease (EC 3.5.1.5). V. On the mechanism of action of urease on urea, formamide, acetamide, $N$-methylurea, and related compounds. Can J Biochem. 58: 1335-1344.

18. Faye, L., Greenwood, J. S. and Chrispeels, M. J. (1986). Urease in jack-bean (Canavalia ensiformis (L.) DC) seeds is a cytosolic protein. Planta. 168: 579-585.

19. Follmer, C., Barcellos, G.B.S., Zingali, R.B., Machado, O.L.T., Alves, E.W., Barja-Fidalgo, C., Guimaräes, J.A. and Carlini, C.R. (2001). Canatoxin, a toxic protein from jack beans (Canavalia ensiformis), is a variant form of urease (EC 3.5.1.5): biological effects of urease independent of its ureolytic activity. Biochem J. 360: 217-224.

20. Follmer, C., Wassermann, G.E. and Carlini, C.R. (2004). Separation of jack bean (Canavalia esiformis) urease isoforms by immobilized metal affinity chromatography and characterization of insecticidal properties unrelated to ureolytic activity. Plant Sci. 167: 241-246.

21. Follmer, C. (2008). Insights into the role and structure of plant ureases. Phytochemistry. 69: $1-28$.

22. Gallardo, F., Fu, J., Canton, F.R., GarciaGutierrez, A., Canovas, F.M. and Kirby, E.G. (1999). Expression of a conifer glutamine synthetase gene in transgenic poplar. Planta. 210: 19-26.

23. Gasser, J.K.R. (1964). Urea as a fertilizer. Soils Fert. 27: 175-180.

24. Goldraij, A., Beamer, L.J. and Polacco, J.C. (2003). Interallelic complementation at the ubiquitous urease coding locus of soybean. Plant Physiol. 132: 1801-1810.

25. Gould, W.D., Hagedorn, C. and McCready R.G.L. (1986). Urea transformations and fertilizer efficiency in soil. Adv Agronomy. 40: 209-237.

26. Granick, S. (1937). Urease distribution in plants: general methods. Plant Physiol. 12: 471486

27. Hirai, M., Kawai-Hirai, R., Hirai, T. and Ueki, T. (1993). Structural change of jack bean urease induced by addition of surfactants studied with synchrotron-radiation small-angle X-ray scattering. Eur J Biochem. 215: 55-61.

28. Hirayama, C., Sugimura, M., Saito, H. and Nakamura, M. (2000). Purification and properties of urease from leaf of mulberry, Morus alba. Phytochemistry. 53: 325-330.

29. Hoffman, A.S. (2002). Hydrogels for biomedical applications. Adv Drug Deliv Rev. 43: 3-12.

30. Holland, M.A., Griffin, J.D., Meyer-Bothling, L.E. and Polacco, J.C. (1987). Developmental genetics of the soybean urease isozymes. Develop Genet. 8: 375-387.

31. Jabri, E., Carr, M.B., Hausinger, R.P. and Karplus, P.A. (1995). The crystal structure of urease from Klebsiella aerogenes. Science. 268: 998-1004.

32. Jabri, E., Lee, H.L., Hausinger, R.P. and Karplus, P.A. (1992). Preliminary crystallographic studies of urease from jack bean and from Klebsiella aerogenes. J Mol Biol. 227: 934-937.

33. Jeffries, C.D. (1964). Urease activity of intact and disrupted bacteria. Arch Pathol. 77: 544547.

34. Kayastha, A.M. and Srivastava, P.K. (2001). Pigeonpea (Cajanus cajan L.) urease immobilized on glutaraldehyde-activated chitosan beads and its analytical applications. Appl Biochem Biotechnol. 96: 41-53.

35. Krajewska, B. (2004). Application of chitinand chitosan-based materials for enzyme immobilizations: a review. Enz Microb Tech. 35: 126-139.

36. Krogmeier, M.J., McCarty, G.W. and Bremner, J.M. (1989). Potential phytotoxicity associated with the use of soil urease inhibitors (phenylphosphorodiamdate / N-(n-butyl) thiophosphoric triamide. Proc Nat Acad Sci USA. 86: 1110-1112.

37. Kucharski, J. (1992). The effect of urease inhibitor (PPDA) on winter wheat yield and on soil microorganisms activity. Pol J Soil Sci. 25: 171-176.

38. Kumar, S., Dwevedi, A. and Kayastha, A.M. (2009). Immobilization of soybean (Glycine max) urease on alginate and chitosan beads showing improved stability: Analytical applications. J Mol Cata B: Enzymatic. 58: 138145.

39. Kumar, S., Kansal, A. and Kayastha, A.M. (2005). Immobilization of jack bean (Canavalia ensiformis) urease on gelatin and its characterization. Orien Pharm Experm Med. 5(1): 43-47. 
40. Kumar, S. and Kayastha, A.M. (2010). Acetohydroxamic acid: a competitive inhibitor of urease from soybean (Glycine max). J Proteins and Proteomics. 1(1): 3-8.

41. Kumar, S. and Kayastha, A.M. (2010). Inhibition studies of soybean (Glycine max) urease with heavy metals, sodium salts of mineral acids, boric acid and boronic acids. J Enzy Inhib Medicinal Chem. 25(5): 646-652.

42. Kumar, S. and Kayastha, A.M. (2010). Soybean (Glycine max) urease: role of sulfhydryl groups in urea catalysis. Plant Physio. Biochem. 48: 746-750.

43. Lea, P.J., Hughes, J.S. and Miflin, B.J. (1979). Glutamine-dependent and asparagine-dependent protein synthesis in maturing legume cotyledons cultured in vitro. J Exp Bot. 30: 529537.

44. Limami, A., Phillipson, B., Ameziane, R., Pernollet, N., Jiang, Q., Roy, R., Deleens, E., Chaumont-Bonnet, M., Gresshoff, P.M. and Hirel, B. (1999). Does root glutamine synthetase control plant biomass production in Lotus japonicus L. Planta. 209: 495-502.

45. Malhi, S.S., Oliver, E., Mayerle, G., Kruger, G. and Gill, K.S. (2003). Improving effectiveness of seedrow-placed urea with urease inhibitor and polymer coating for durum wheat and canola. Commun Soil Sci Plant Anal. 34: 17091727.

46. McCarty, G.W., Bremner, J.M. and Lee, J.S. (1990). Inhibition of plant and bacterial ureases by phosphoramides. Plant and Soil. 127: 269283.

47. McDonald, J. A., Voraben, J. E. and Campbell, J. W. (1980). Invertebrate urease: purification and properties of the enzyme from a land snail. Otala lactea. Comp Biochem Physiol B. 66: 223-231.

48. McLean, R. J. L., Cheng, K.J., Gould, W. D. and Costerton, J. W. (1985). Cytochemical localization of urease in a rumen Staphylococcus sp. by electron microscopy. Appl. Environ. Microbiol. 49: 253-255.

49. McLean, R.J.L., Cheng, K.J., Gould, W.D., Nickel, J.C. and Costerton, J.W. (1986). Histochemical and biochemical urease localization in the periplasm and outer membrane of two Proteus mirabilis strains. Can. J. Microbiol. 32: 772-778.

50. Merino, P., Estavillo, J.M., Graciolli, L.A., Pinto, M., Lacuesta, M., Munoz-Rueda, A. and Gonzalez-Murua, C. (2002). Mitigation of $\mathrm{N}_{2} \mathrm{O}$ emissions from grassland by nitrification inhibitor and Actilith F2 applied with fertilizer and cattle slurry. Soil use and management. 18: 135-141.

51. Mobley, H.L., Island, M.D. and Hausinger, R.P. (1995). Molecular biology of microbial ureases. Microbiol Rev. 59: 451-480.

52. Mobley, H.L.T. and Hausinger, R.P. (1989). Microbial ureases: significance, regulation, and molecular characterization. Microbiol Rev. 53: 85-108.

53. Mulvaney, R.L. and Bremner, J.M. (1981). Control of urea transformations in soils. In: Soil Biochemistry (Ed. Paul, E.A. and Ladd, J.N.) Marcel Dekker Inc, New York. Vol 5, pp. 153196.

54. Polacco, J.C. and Holland, M.A. (1993) Roles of urease in plant cells. In: International Review of Cytology (Eds. Jeon, K.W. and Jarvik, J.) Academic Press, Inc San Diego. Vol. 145, pp. 65-103.

55. Polacco, J.C., Judd, A.K., Dybing, J.K. and Cianzio, S.R. (1989). A new mutant class of soybean lacks urease in leaves but not in leaf derived callus or in roots. Mol Gen Genet. 217: 257-262.

56. Polacco, J.C., Krueger, R.W. and Winkler, R.G. (1985). Structure and possible ureide degrading function of the ubiquitous urease of soybean. Plant Physiol. 79: 794-800.

57. Polacco, J.C. and Sparks, R.B. (1982). Patterns of urease synthesis in developing soybeans. Plant Physiol. 70: 189-194.

58. Polacco, J.C. and Winkler, R.G. (1984). Soybean Leaf Urease: A Seed Enzyme? Plant Physiol. 74: 800-803.

59. Polacco, J.C. (1977). Is nickel a universal component of plant ureases? Plant Sci Lett. 10: 249-255.

60. Prakash, O. and Bhushan, G. (1997). Isolation, purification and partial characterization of urease from seeds of watermelon (Citrullus vulgaris). J Plant Biochem Biotechnol. 6: 4547.

61. Prakash, O. and Upadhyay, L.S.B. (2003). Effect of thiols on the activity of urease from dehusked seeds of watermelon (Citrullus vulgaris). Plant Sci. 164: 189-194.

62. Prasad, R. and Power, J. (1995). Nitrification inhibitors for agriculture, health and the environment. Adv Aron. 54:233-2281.

63. Hausinger, R.P. and Karplus, P.A. (2001). Urease, In: Handbook of Metalloproteins (Eds. Wieghardt, K., Huber, R., Poulos, T.L. and Messerschmidt, A.). Wiley, West Sussex UK, pp. 867-879.

64. Radel, R.J., Gateney, J. and Peters, G.E. (1988). Urease inhibitor Developments. In: American 
volatilization from urea fertilizers (Eds. Back, B. and Kissel, D.) Tennessee Valley Authority, Muscle Shoals AL. pp. 111-136.

65. Reddy, K.R.C., Srivastava, P.K., Dey, P.M. and Kayastha, A.M. (2004). Immobilization of pigeonpea (Cajanus cajan) urease on DEAEcellulose paper strips for urea estimation. Biotechnol Appl Biochem. 39: 323-327.

66. Rinaudo, M. (2008). Main properties and current applications of some polysaccharides as biomaterials. Polym Int. 57: 397-430.

67. Rosenstein, I.J.M. and Hamilton-Miller, J.M.T. (1984). Inhibitors of urease as chemotherapeutic agents. Crit Rev Microbiol. 11: 1-12.

68. Ciurli, S. and Mangani, S. (2001). Nickelcontaining enzymes, In: Handbook on Metalloproteins (Eds. Bertini, I., Sigel, A. and Sigel, H. Marcel Dekker, New York, pp. 669707.

69. Sheldon, R.A. (2007). Enzyme Immobilization: The Quest for Optimum Performance. Adv Synth Catal. 349: 1289-1307.

70. Srivastava, P.K., Kayastha, A.M., and Srinivasan (2001). Characterization of gelatinimmobilized pigeonpea urease and preparation of a new urea biosensor. Biotechnol Appl Biochem. 34: 55-62.

71. Srivastava, P.K. and Kayastha, A.M. (2000). Significance of sulfhydryl groups in the activity of urease from pigeonpea (Cajanus cajan L.) seeds. Plant Sci. 159: 149-158.

72. Stebbins, N., Holland, M.A., Cianzio, S.R. and Polacco, J.C. (1991). Genetic tests of the roles of the embryonic ureases of soybean. Plant Physiol. 97: 1004-1010.

73. Stebbins, N.E. and Polacco, J.C. (1995). Urease is not essential for ureide degradation in soybean. Plant Physiol. 109: 169-175.

74. Stitt, M. (1999). Nitrate regulation of metabolism and growth. Curr Opin Plant Biol. 2: $178-186$.

75. Sumner, J.B. (1926). The isolation and crystallization of the enzyme urease. J Biol Chem. 69: 435-441.

76. Swati, M., Kumar, S., Reddy, K.R.S. and Kayastha, A.M. (2007). Immobilization of urease from pigeonpea (Cajanas cajan) on agar tablets and its application in urea assay. Applied Biochem Biotechnol. 142: 291-297.

77. Takeuchi, T. (1909). On the occurrence of urease in higher plants. J Coll Ar Imp Univ. 1:
1-14.Tange, Y. and Niwa, O. (1997). Identification of the ure1+ gene encoding urease in fission yeast. Curr Genet. 32: 244246.

78. Thompson, J.F., Madison, J.T. and Muenster, A.E. (1977). In vitro culture of immature cotyledons of soybean (Glycine max L. Merr). Ann Bot. 41: 29-39.

79. Todd, M.J. and Hausinger, R.P. (1989). Competitive inhibitors of Klebsiella aerogenes urease. Mechanisms of interaction with the nickel active site. J Biol Chem. 264: 15835-42.

80. Todd, M.J. and Hausinger, R.P. (2000). Fluoride inhibition of Klebsiella aerogenes Urease: mechanistic implication of a pseudouncompetitive, slow binding inhibitor. Biochemistry. 39: 5389-5396.

81. Tomlinson, T.E. (1970). Urea agronomic applications. Proc Fert Soc. 113, 1-76.

82. Torisky, R.S. and Polacco, J.C. (1990). Soybean Roots Retain the Seed Urease Isozyme Synthesized during Embryo Development. Plant Physiol. 94: 681-689.

83. Varner, J.E. (1959). Urease. In: The enzymes. (Eds. Boyer, P.D., Lardner, H. and Myrback, K.) Academic Press Inc, New York. Vol. 4, pp. 247-256.

84. Vogels, G. and van der Drift, C. (1976). Degradation of purines and pyrimidines by microorganisms. Bacteriol Rev. 40: 403-468.

85. Wang, X.B., Xin, J.F., Grant, C.A. and Bailey, L.D. (1995). Effects of placement or urea with the urease inhibitor on seedling emergence, $\mathrm{N}$ uptake and dry matter yield of wheat. Can J Plant Sci. 75: 449-452.

86. Williamson, J.C., Taylor, M.D., Torrens, R.S. and Vojvodic-Vukovic, M. (1998) Reducing nitrogen leaching from dairy farm effluentirrigated pasture using dicyandiamide: a lysimeter study. Agri Ecosys Environ. 69: 8188.

87. Wiren, N., Gazzarrini, S., Gojon, A. and Frommer, W.B. (2000). The molecular physiology of ammonium uptake and retrieval. Curr Opin Plant Biol. 3: 254-261.

88. Zerner, B. (1991). Recent advances in the chemistry of an old enzyme, urease. Bioorg Chem. 116-131.

89. Zerulla, W., Kummer, K., Wissemeier, A. and Radle, M. (2000). The development and testing a new nitrification inhibitor. Internat Fert Soc Proc, No. 455: 5-23. 